\title{
Genetic Structure of Brazilian Populations of White Mouth Croaker Micropogonias furnieri (Perciformes : Sciaenidae)
}

\author{
Angela Puchnick-Legat ${ }^{1 *}$ and José Alberto Levy ${ }^{2}$ \\ ${ }^{1}$ Embrapa Meio-Norte; Unidade de Execução de Pesquisa de Parnaíba; C. P. 341; 64200-000; \\ angela@cpamn.embrapa.br; Parnaíba - PI - Brasil. ${ }^{2}$ Laboratório de Bioquímica Marinha; Departamento de \\ Química; Fundação Universidade Federaldo Rio Grande; levy@mikrus.com.br; Rio Grande - RS - Brasil
}

\begin{abstract}
Mitochondrial (mt) DNA population structure was examined by using restriction fragment length polymorphism analysis (RFLP) among 149 white mouth croakers (Micropogonias furnieri) sampled from six locations in the Brazilian coast. Heterogeneity tests revealed no differentiation in mtDNA haplotype frequencies within the region between $23^{\circ} \mathrm{S}$ and $34^{\circ} \mathrm{S}(\mathrm{P}=0.263)$, but significant heterogeneity was detected between north and south of $23^{\circ} \mathrm{S}$ $(P<0.003)$. Analysis of molecular variance (AMOVA) indicated a low $F_{S T}$ value $(0.008, P=0.180)$ among southcentral localities $\left(23-34^{\circ} \mathrm{S}\right)$, but a significant level of population subdivision $\left(F_{S T}=0.322, P<0.003\right)$ between north and south-central localities. UPGMA analysis of mtDNA sequence divergence revealed differentiation between white mouth croakers collected from north and south of $23^{\circ} \mathrm{S}$. Mantel test found significant association between matrices of genetic distance and geographic distance among samples. Collectively, these data were consistent with a single genetic stock of Micropogonias furnieri in the Brazilian coast, with semi-isolated populations occurring in the north and south of $23^{\circ} \mathrm{S}$.
\end{abstract}

Key words: Genetic population structure, mitochondrial DNA, RFLP, Micropogonias furnieri

\section{INTRODUCTION}

White mouth croaker (Micropogonias furnieri) is a euryhaline sublittoral sciaenid fish that uses estuarine and coastal waters as nursery and feeding grounds for larvae and juveniles. The species is distributed from the Yucatan Peninsula, Gulf of Mexico, at $20^{\circ} \mathrm{N}$, to the Gulf of San Matias, Argentina, at $41^{\circ} \mathrm{S}$ (Chao, 1978), but it is particularly abundant on the southeastern shelf of Brazil (south of $23^{\circ} \mathrm{S}$ ) and the shelf of Uruguay. $M$. furnieri is an important commercial fishery resource along the Southwestern Atlantic shelf. Population dynamics, distribution and abundance vary considerably on both a spatial and temporal

\footnotetext{
${ }^{*}$ Author for correspondence
}

basis, especially in the southern part of the species' range, and appear to be related to environmental factors. In view of their widespread distribution, M. furnieri inhabit water masses with different temperature - salinity combinations. This species is found all year in estuaries and brackish waters that vary from 0.1 to $32.8 \%$ and from 11 to $28{ }^{\circ} \mathrm{C}$, and also in waters where winter temperatures and salinities average $9{ }^{\circ} \mathrm{C}$ and 20 $\%$ o, respectively. Off the coast it is common in waters of $30 \%$, and 13 to $25^{\circ} \mathrm{C}$ (Isaac, 1988). Analyses of the catch per unit effort (CPUE) for $M$. furnieri indicate constant levels of abundance throughout the year between $23^{\circ} \mathrm{S}$ and $28^{\circ} \mathrm{S}$, and a systematic variation in abundance with season in waters off southern Brazil between $28^{\circ} \mathrm{S}$ and $35^{\circ}$ 
S (Vazzoler, 1963). Variation in abundance off southern Brazil and Uruguay suggest that fish population migrate southward during summer $\left(32^{\circ} \mathrm{S}-35^{\circ} \mathrm{S}\right)$ and northward during winter $\left(28^{\circ} \mathrm{S}\right.$ $-31^{\circ} \mathrm{S}$ ), according to the seasonal displacements of the convergence of subtropical and subantarctic waters (Vazzoler and Santos,1965; Paiva-Filho, 1977). The subtropical convergence system is situated off the coast of Uruguay $\left(35^{\circ} \mathrm{S}\right)$ during summer and north of Santa Catarina $\left(27-28^{\circ} \mathrm{S}\right)$ in winter (Emilsson, 1961) and represents a marked transition of temperature and salinity, governing biological production and trophic interactions (Oderbrecht and Castello, 2001).

Recently, concern has been expressed over the apparent decline in the white mouth croaker fishery along the coast of Brazil, Uruguay and
Argentina (Haimovici, 1998). Distinct coastal zone policies and the absence of comparable information on status and trends of the ecosystem have been an obstacle towards an integrated fishery management program among these countries (Oderbrecht and Castello, 2001).

One important question to present and future management is whether discrete breeding units or populations occur within the species range. The status of white mouth croaker populations north of $23^{\circ} \mathrm{S}$ has not been well investigated, although combined data on reproductive features suggest the existence of a population between $6^{\circ} \mathrm{N}$ and $2^{\circ}$ S (Lowe-McConnel, 1966; Juras, 1984). Available information on population structure south of $23^{\circ} \mathrm{S}$ appears contradictory.

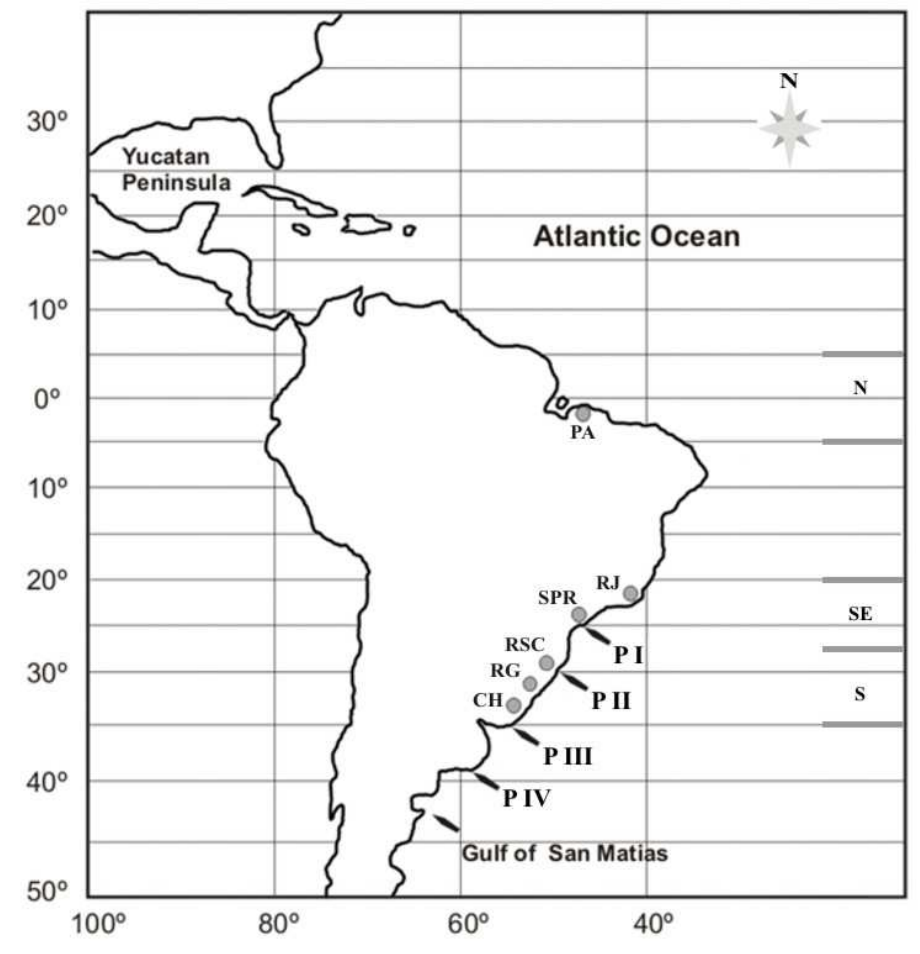

Figure 1 - Distribution of M. furnieri on the Atlantic Ocean (modified from Isaac, 1988). PI, PII, PIII, and PIV represent the four hypothesized populations based on biology and morphological studies. N, SE and S are coastal Brazilian regions defined based on environmental characteristics and types of fishing activities. Gray spots (CH, RG, RSC, SPR, RJ and PA) are the six collection sites of the present study.

Geographic variation in meristic characters, body proportions, reproductive and growth features suggest the existence of four partially isolated populations of M. furnieri along the southwestern Atlantic (Fig. 1). Vazzoler (1971) described two different populations in the region between $23^{\circ} \mathrm{S}$ and $33^{\circ} \mathrm{S}$ : population I $\left(23-29^{\circ} \mathrm{S}\right)$, with a spawning area in the estuarine lagoon region of Cananéia $\left(25-26^{\circ} \mathrm{S}\right)$, and population II that spawned in the Lagoa dos Patos $\left(32^{\circ} \mathrm{S}\right)$ and other 
coastal waters off Rio Grande do Sul (29-33 S). In the Rio de la Plata region and coastal waters of Uruguay and Argentina, Alamón (1983) reported that $M$. furnieri probably formed one population with spawning and nursery areas in the Rio de la Plata (population III, between $35^{\circ} \mathrm{S}$ and $38^{\circ} \mathrm{S}$ ), and another population distributed along the oceanic coast of Uruguay and the southern Brazil (population II). Cotrina (1986) suggested the existence of a fourth population with a spawning area in Bahia Blanca $\left(39-40^{\circ} \mathrm{S}\right)$.

Genetic studies of $M$. furnieri using starch-gel electrophoresis of allozymes did not support the multiple-stock hypothesis and confirmed the existence of a single population unit along the southwestern Atlantic coast. Maggioni et al. (1994) and Levy et al. (1998) found a high degree of genetic homogeneity in allele frequencies and also high levels of gene flow among white mouth croaker sampled from regions between $23^{\circ} \mathrm{S}$ and $40^{\circ} \mathrm{S}$.

Recent studies have shown that restriction fragment length polymorphism analysis (RFLP) of mtDNA is more powerful than protein electrophoresis for differentiating populations within several economically important fish species (Avise, 1994). MtDNA is a haploid, circular, and non-recombinant molecule that evolves rapidly and provides character states whose phylogenetic relationships can be deduced (Wilson et al., 1985). The geographic distribution of branches in an intraspecific mtDNA phylogeny constitutes the maternal phylogeographic patterns of a species (Avise et al., 1987). In the present work, we examined mitochondrial DNA (mtDNA) population structure in $M$. furnieri along the Brazilian coast between $1^{\circ} \mathrm{S}$ and $34^{\circ} \mathrm{S}$ latitude. Our purposes were to (1) estimate levels of genetic variation within and between localities from Brazilian coast, (2) estimate levels of genetic divergence among localities, and (3) further test the hypothesis that white mouth croaker populations are spatially subdivided, to provide an improved basis for future fishery management.

\section{MATERIALS AND METHODS}

Micropogonias furnieri of Brazilian coastal areas were obtained from commercial fishery during late 1999 and early 2000. Freshly caught tissue samples were removed and preserved at $95 \%$ ethanol for genetic analyses. Code names and locations of sample collections are presented in Fig. 1 and Table 1. Sample localities represent the southern (S), southeastern (SE), and northern (N) regions of the species' Brazilian coast range. Regions were defined based on environmental characteristics and types of fishing activities, as suggested by Matsuura (1995). Pooled southeast (SPR and RJ) and southern (CH, RG and RSC) sample localities also represented the geographical distribution of populations I and II, RG and SPR respectively corresponding to the spawning areas of these hypothesized populations.

PA sample was included in analyses to test for population identity in the northern Brazil and was compared to south and southeastern localities for investigating population differentiation among north and south region of $23^{\circ} \mathrm{S}$. Collections along the northeastern coast could not be made in this study.

Mitochondrial DNA population structure was examined by using polymerase chain reaction (PCR) and restriction fragment length polymorphism analysis (RFLP). MtDNA extracts were obtained by the procedure of Chow and Inowe (1993). Primers L-THR (5'-3': AGC TCA GCG CCA GAG CGC CGG TCT TGT AAA) and 12 SAR-H (5'-3': ATA GTG GGG TAT CTA ATC CCA GGT) were used in PCR to amplify a $1450 \mathrm{bp}$ product of mtDNA containing the entire D-loop region, tRNA-Pro and tRNA-Phe genes, and portions of the tRNA-Thr and 12S rRNA genes (Lankford Jr. et al., 1999). Amplifications were performed in $50 \mu \mathrm{l}$ reaction volume containing 1X PCR Buffer, 0.2 mM of dNTP, 2.0 $\mathrm{mM}$ of $\mathrm{MgCl}_{2}, 30$ pmol of each primer, $1.5 \mathrm{U}$ of Taq polymerase, and $20 \mathrm{ng}$ of DNA template. PCR reactions were programmed for 35 cycles at $94^{\circ} \mathrm{C}$ for $1 \mathrm{~min}, 65^{\circ} \mathrm{C}$ for $1 \mathrm{~min}$ and $72^{\circ} \mathrm{C}$ for $2 \mathrm{~min}$, including a final extension at $72^{\circ} \mathrm{C}$ for $8 \mathrm{~min}$ in the last cycle.

PCR products were digested with the following nine restriction endonucleases: Bgl I, EcoR I, EcoR V, Hae III, Hinf I, Hpa II, Pst I, Rsa I, and Sac II. Variant RFLP patterns were separated by gel electrophoresis on $1.5 \%$ agarose gels and visualized after ethidium bromide with UV light illumination (Sambrook et al., 1989). Fragment sizes were estimated by using $1 \mathrm{~Kb}$ DNA ladder and $\varnothing 174$ - Hae III molecular weight markers, and UVIdoc software program, ver. 98.01. 
Table 1 - White mouth croaker collection data.

\begin{tabular}{|c|c|c|c|c|}
\hline Sample & Location & Date & $\mathbf{N}$ & Coastal region \\
\hline $\mathrm{CH}$ & $\begin{array}{l}\text { Chui (RS) } \\
33^{\circ} 41^{\prime} \mathrm{S} \\
53^{\circ} 27^{\prime} \mathrm{W}\end{array}$ & $\begin{array}{c}\text { Mar } \\
2000\end{array}$ & 16 & S \\
\hline $\mathrm{RG}$ & $\begin{array}{c}\text { Rio Grande (RS) } \\
32^{\circ} 00^{\prime} \mathrm{S} \\
52^{\circ} 20^{\prime} \mathrm{W}\end{array}$ & $\begin{array}{c}\text { Dec } \\
1999\end{array}$ & 32 & S \\
\hline $\mathrm{RSC}$ & $\begin{array}{c}\text { Torres (RS) } \\
29^{\circ} 20^{\prime} \mathrm{S} \\
49^{\circ} 43^{\prime} \mathrm{W}\end{array}$ & $\begin{array}{c}\text { Dec } \\
1999\end{array}$ & 25 & $S$ \\
\hline SPR & $\begin{array}{c}\text { Paranaguá (PR) } \\
\text { Cananéia (SP) } 25^{\circ} 31^{\prime} \\
\mathrm{S} \\
48^{\circ} 30^{\prime} \mathrm{W}\end{array}$ & $\begin{array}{c}\text { Jan } \\
2000\end{array}$ & 37 & SE \\
\hline RJ & $\begin{array}{l}\text { Itaipu (RJ) } \\
22^{\circ} 54^{\prime} \mathrm{S} \\
43^{\circ} 13^{\prime} \mathrm{W}\end{array}$ & $\begin{array}{c}\text { Feb } \\
2000\end{array}$ & 28 & SE \\
\hline PA & $\begin{array}{c}\text { Ajuruteua (PA) } \\
01^{\circ} 03^{\prime} \mathrm{S} \\
46^{\circ} 46^{\prime} \mathrm{W} \\
\end{array}$ & $\begin{array}{c}\text { Apr } \\
2000\end{array}$ & 11 & $\mathrm{~N}$ \\
\hline
\end{tabular}

Distinctive RFLP patterns were identified by letter codes and combined to produce composite mtDNA haplotypes for each individual fish.

Statistical analyses were performed with the Arlequin Package, ver. 2000 (Schneider et al., 2000). Gene diversity and nucleotide diversity were calculated for each sample and for the pooled samples, according to Nei (1987). The distribution of mtDNA haplotype frequencies was evaluated for homogeneity between samples using P-exact test of population differentiation (Raymond and Rousset, 1995) and a total of 10,000 steps in Markov chain. $P$-values $<0.003$ were considered as significantly different, after Bonferroni sequential procedure. Population structure in $M$. furnieri was also calculated by using a hierarchical analysis of molecular variance (AMOVA, Excoffier et al., 1992). Samples were stratified by locality (PA, RJ, SPR, RSC, RG, and $\mathrm{CH}$ ) and nested within region (N, SE, and $\mathrm{S})$. Total genetic variation was partitioned into covariance components "within geographic localities", "among geographic localities", and "between regions". Covariance components were used to compute fixation indices in terms of inbreeding coefficients. The significance of fixation indices was tested using 1,000 random permutations to generate null distributions for each variance component. An Euclidian distance matrix between pairs of haplotypes was used for the computation of a minimum spanning tree between haplotypes, and also for the calculation of pairwise $F_{\mathrm{ST}}$ values as short-term distances between populations. The null distribution of pairwise $F_{\mathrm{ST}} \mathrm{S}$ under the hypothesis of no difference between populations was obtained by permuting haplotypes between populations. $P$-values $<0.003$ were considered as significantly different. Percent mean nucleotide sequence divergences within and among samples were estimated by the average number of pairwise differences within and between populations (Nei and $\mathrm{Li}, 1979$ ). The sample genetic distance matrix was clustered using unweigthed pair-group method with arithmetic means (UPGMA) in Inference Phylogeny Package (PHYLIP), version 3.5 (Felsestein, 2000). A matrix correlation (Mantel) test was carried out between the sample genetic distance matrix and a matrix of geographic distances (in miles) between all pairs of sample localities. A total of 1,000 permutations were employed to test the significance level of the Mantel correlation.

\section{RESULTS AND DISCUSSION}

RFLP analysis of the D-loop regions revealed a total of 23 unique fragments, 16 restriction sites 
and five composite mtDNA haplotypes in $M$. furnieri collected from the Brazilian coast (Table 2). Only two of the nine enzymes employed (Hinf I and Rsa I) produced variant patterns. The digestion profiles of variants were consistent with the hypothesis of single gains or losses of restriction sites.

Of the 149 individuals surveyed, $116(78 \%)$ shared the same haplotype. Haplotype 1 (h1) was numerically dominant ( $>0.70 \%$ frequency) at all localities, except northern sample (PA, 0.45\% frequency). The haplotype 4 occurred at $0.55 \%$ frequency in PA, at low $(<0.18 \%)$ frequencies in the other samples, and it was absent in $\mathrm{CH}$ sample. The haplotype 3 was present at $25 \%$ frequency in $\mathrm{CH}$, at very low $(<0.08 \%)$ frequencies in the other samples and it was absent in PA. The haplotype 2 occurred at low $(<0.12 \%)$ frequencies in $\mathrm{RG}$ and RSC samples and the haplotype 5 at $0.04 \%$ frequency only in RSC sample. The minimum spanning tree between all pairs of haplotypes showed that geographically segregated haplotypes were closely related (1-2 restriction site changes) to the common haplotype (h1).

Gene diversity averaged $0.388 \pm 0.097$ (mean \pm SE) for the pooled sample and ranged from 0.203 \pm 0.084 in SPR to $0.546 \pm 0.072$ in PA. Nucleotide diversity also varied geographically, ranging from $\pi=0.086 \pm 0.071$ in SPR to $\pi=0.216 \pm 0.141$ in RSC (Table 3). Estimates of gene and nucleotide sequence diversities indicated that mtDNA variation in $M$. furnieri was lower than that in most other marine fish species surveyed to date (Gold and Richardson, 1991; Avise, 1994; Lankford Jr. et al. 1999). Mean values were only larger than those reported for the weakfish Cynoscion regalis (Graves et al., 1992) and the Atlantic black sea bass Centropomus striata (Bowen and Avise, 1990).

Table 2 - Distribution of Micropogonias furnieri mtDNA haplotypes based on restriction endonucleases among different collections. The order of restriction enzyme morphs, represented from left to right, is HinfI and RsaI.

\begin{tabular}{cccccccc}
\hline \multicolumn{7}{c}{ Haplotype } & \multicolumn{7}{c}{ Sample } & Total \\
\hline h1 (AA) & CH & RG & RSC & SPR & RJ & PA & \\
h2 (AB) & 0 & 27 & 17 & 33 & 22 & 5 & 116 \\
h3 (AC) & 4 & 1 & 3 & 0 & 0 & 0 & 4 \\
h4 (BA) & 0 & 2 & 1 & 3 & 1 & 0 & 11 \\
h5 (BB) & 0 & 0 & 3 & 1 & 5 & 6 & 17 \\
Total & 16 & 32 & 25 & 37 & 28 & 0 & 1 \\
\hline
\end{tabular}

Table 3 - Gene and nucleotide diversity (mean \pm SE) in M. furnieri collected from the Brazilian coast.

\begin{tabular}{ccc}
\hline Sample Locality & $\begin{array}{c}\text { Gene } \\
\text { Diversity }\end{array}$ & Nucleotide Diversity \\
\hline CH & $0.400 \pm 0.114$ & $0.178 \pm 0.125$ \\
RG & $0.288 \pm 0.102$ & $0.113 \pm 0.087$ \\
RSC & $0.527 \pm 0.110$ & $0.216 \pm 0.141$ \\
SPR & $0.203 \pm 0.084$ & $0.086 \pm 0.071$ \\
RJ & $0.362 \pm 0.100$ & $0.133 \pm 0.098$ \\
PA & $0.546 \pm 0.072$ & $0.182 \pm 0.131$ \\
\hline
\end{tabular}

Average nucleotide divergence within (1.362\%) and among $(0.248 \%)$ pooled samples indicated that most of observed mtDNA variation occurred within geographic localities. There were no significant levels of mtDNA divergence between southeast and southern localities (except between $\mathrm{RJ}$ and $\mathrm{CH}$ samples), but significant differences occurred between northern (PA) and all others samples (Table 4). 
UPGMA clustering-analysis of mtDNA genetic distances (Table 4) indicated that white mouth croaker from the north and the south of $23^{\circ} \mathrm{S}$ were genetically distinguishable from one another (Fig. 2 ). The correlation (Mantel) test between matrices of sample genetic distances and geographic distances was significantly different from zero (0.883, $P<0.003)$, and revealed a geographic component to the distribution of mtDNA haplotypes in M. furnieri.

AMOVA also revealed that the majority $(87.24 \%)$ of mtDNA variation in $M$. furnieri occurred within sample localities $(P<0.002)$. A significant portion (3.72\%) was attributable to differences among localities $(P=0.047)$, but variation between regions $(9.04 \%)$ was not significantly structured $(P=0.112)$. Pairwise $F_{\mathrm{ST}}$ values ranged from -
0.023 to 0.446 and averaged 0.134 (Table 5). The $F_{\mathrm{ST}}$ value found in $M$. furnieri was higher than those reported in other sciaenid: 0.046 for Micropogonias undulates (Lankford Jr. et al. 1999), and 0.057 for Sciaenops ocellatus (Gold and Richardson, 1991).

Population structure in $M$. furnieri was indicated by genetic differentiation between $\mathrm{PA}$ and $\mathrm{CH}$ sample localities $\left(F_{\mathrm{ST}}=0.387, P<0.003\right)$, which represented both limits of the species' range in this study $\left(1^{\circ} \mathrm{S}-34^{\circ} \mathrm{S}\right)$. Differentiation was also observed between PA and RG, and PA and SPR localities. PA, SPR, and RG respectively represented spawning areas of $M$. furnieri on the north, southeast and southern Brazilian shelf.

Table 4 - Average number of pairwise differences (Nei and Li, 1979) within population (diagonal elements) and between populations (above diagonal). Below diagonal: corrected average pairwise difference. Bolded elements were estimated as significantly different $(P<0.05)$.

\begin{tabular}{lcccccc}
\hline & CH & RG & RSC & SPR & RJ & PA \\
\hline CH & 1.600 & 1.375 & 1.880 & 1.243 & 1.607 & 2.636 \\
RG & 0.066 & 1.018 & 1.496 & 0.876 & 1.121 & 1.963 \\
RSC & 0.107 & 0.014 & 1.947 & 1.422 & 1.593 & 2.233 \\
SPR & 0.056 & -0.021 & 0.061 & 0.775 & 1.032 & 1.953 \\
RJ & $\mathbf{0 . 2 0 8}$ & 0.012 & 0.020 & 0.045 & 1.198 & 1.731 \\
PA & $\mathbf{1 . 0 1 8}$ & $\mathbf{0 . 6 3 6}$ & $\mathbf{0 . 4 4 1}$ & $\mathbf{0 . 7 4 8}$ & $\mathbf{0 . 3 1 3}$ & $\mathbf{1 . 6 3 6}$ \\
\hline
\end{tabular}

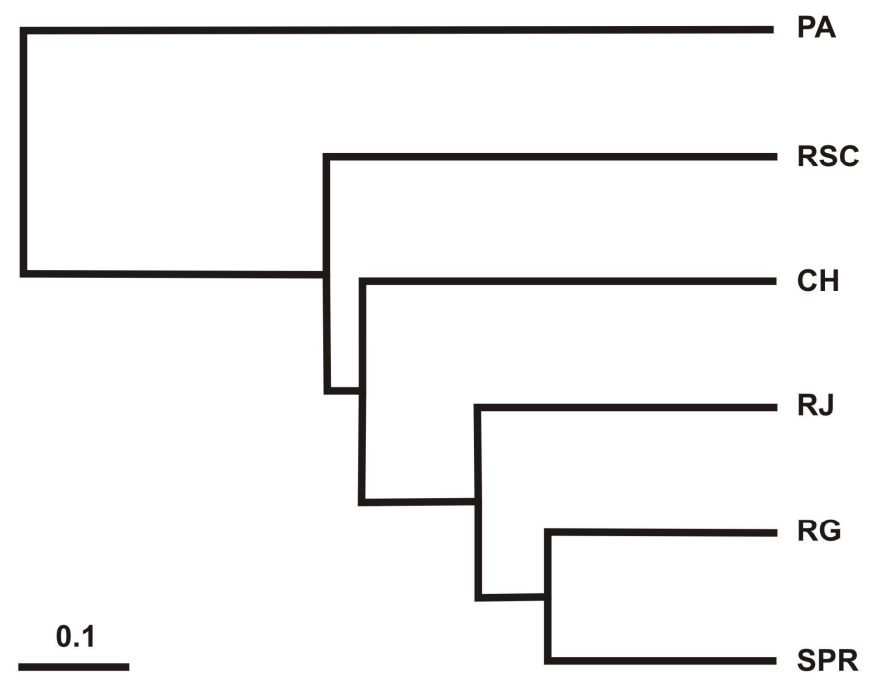

Figure 2 - UPGMA phenogram showing genetic distances (Nei and Li, 1979) among white mouth croaker sample localities. 
Table $5-F_{\mathrm{ST}}$ values of population differentiation in $M$. furnieri along the Brazilian coast. Bolded values were significantly different $(P<0.003)$.

\begin{tabular}{lccccc}
\hline & CH & RG & RSC & SPR & RJ \\
\hline CH & 0.000 & & & & \\
RG & 0.058 & 0.000 & & & \\
RSC & 0.054 & 0.012 & 0.000 & & \\
SPR & 0.065 & -0.023 & 0.052 & 0.000 & \\
RJ & 0.137 & 0.011 & 0.014 & 0.047 & 0.000 \\
PA & $\mathbf{0 . 3 8 7}$ & $\mathbf{0 . 3 5 9}$ & 0.189 & $\mathbf{0 . 4 4 6}$ & 0.198 \\
\hline
\end{tabular}

The P-exact test of population differentiation revealed significant differences $(P<0.003)$ in mtDNA haplotype frequencies between $\mathrm{PA}$ and $\mathrm{CH}$, and between PA and SPR samples. Given the lack of heterogeneity between pooled south $(\mathrm{CH}$, RG and RSC) and southeastern (SPR and RJ) sample localities $(P=0,263 \pm 0,009)$, composite haplotype frequencies were pooled across southcentral localities (23-34 $\mathrm{S}$ ) and compared with the northern sample. Significant heterogeneity in mtDNA frequencies was found in the north versus south region of $23^{\circ} \mathrm{S}$. AMOVA also indicated no significant mtDNA population subdivision between pooled southeast and southern sample localities $\left(F_{\mathrm{ST}}=0.008, P=0.180\right)$, but significant genetic differentiation was found between north and south-central Brazilian coast $\left(\mathrm{F}_{\mathrm{ST}}=0.322, P<\right.$ 0.003).

The geographic structure of any species is a product of both historical and contemporary gene flow and is likely to have been affected by such factors as geographic or ecologic impediments to movement and dispersal capability (Bowen and Avise, 1990). In the case of M. furnieri, dispersal capability on the north and south region of $23^{\circ} \mathrm{S}$ may be affected by geographic variation in environmental factors between the tropical and subtropical circulation of water masses within the Southwestern Atlantic. Stramma and England (1999) demonstrated that subtropical South Atlantic was governed by the subtropical gyre, while the tropical circulation showed several depth-dependent zonal current bands (Fig. 3).

The observed genetic heterogeneity between $M$. furnieri in the north and south of $23^{\circ} \mathrm{S}$ suggested that migration rate was not high enough to preclude genetic divergence of populations by random drift (Slatkin, 1987). Spatial autocorrelation analysis of the distribution of mtDNA divergence over all Brazilian localities indicated that geographically proximate localities were more similar genetically than were more geographically distant localities. The observed autocorrelation was consistent with isolation- bydistance patterns, whereby migration of individuals within the Brazilian shelf was inversely related to geographic distance from sample localities. Although genetic divergence in M. furnieri occurred between north (PA) and all other sample localities, population subdivision was only statistically significant between PA and $\mathrm{CH}$, PA and RG, and PA and SPR. Particularly when the migration rate was small, selection could easily be strong enough to dominate the pattern of genetic differentiation, and either increased or decreased $F_{\mathrm{ST}}$ relative to the neutral case. However, significant assumption of allele neutrality could be an important source of error in the interpretation of population structure statistics and it must be considered with caution (Whitlock and McCauley, 1999). These observations indicated that white mouth croaker population was weakly subdivided, with semi-isolated populations occurring in the north and south region of $23^{\circ} \mathrm{S}$.

In the south of $23^{\circ} \mathrm{S}, \mathrm{mtDNA}$ analysis provided no evidence that $M$. furnieri is subdivided into discrete genetic stocks between south and southeastern Brazil $\left(23^{\circ} \mathrm{S}-34^{\circ} \mathrm{S}\right)$. Frequencyand distance- based analyses both suggested a single, panmictic population. Dispersal capability influenced genetic diversity of south and southeastern populations, but it was not able to cause significant divergence. Low levels of mtDNA divergence between southeast and southern localities $(0.011 \%)$, although not statistically significant, were more consistent with a pattern of semi-isolation by distance rather than marked subdivision by the oceanographic patterns of the subtropical convergence system. 


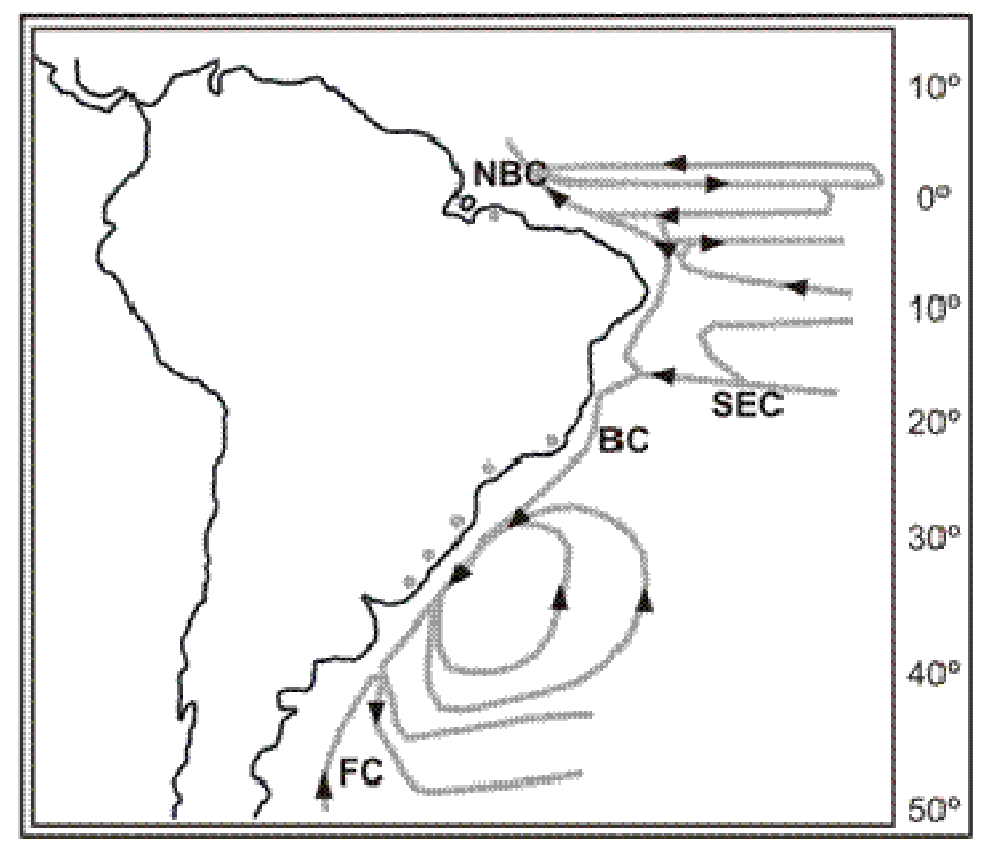

Figure 3 - Circulation of water masses within the South Atlantic Ocean (modified from Stramma and England, 1999). In the northeastern Brazil, the South Equatorial Current (SEC) in the nearsurface layer reaches the shelf of Brazil (near $16^{\circ} \mathrm{S}$ ) and separates into the northward and southward flow of Brazil Current (NBC and BC). The southern Brazil shelf is influenced by the Subtropical Convergence system, made up of the confluence zone of southward flow of BC with the Falkland Current (FC).

MtDNA results supported the hypothesis of contemporary gene flow among south-central Brazilian coast and were in agreement with previous allozyme data reported by Levy et al. (1998), suggesting that migration rate among white mouth croaker populations was high enough to maintain the homogeneity in gene frequencies and therefore, avoided differentiation by genetic drift. The lack of genetic heterogeneity found within $M$. furnieri in both mtDNA and nuclear gene frequencies was supported by several aspects of the physical environment and white mouth croaker life history, which should facilitate dispersal and minimize geographic subdivision within the south-central Brazil. Lima et al. (1996) showed that the general form of the circulation of water masses in the southern Brazilian shelf could be characterized by a combination of different processes that presented high levels of gene flow in this area. M. furnieri are long-lived pelagic spawners (Vazzoler, 1971), meaning that individuals could spawn at multiple localities throughout their life-times. Since adult spawn near the mouths of bays or estuaries (Isaac, 1988), pelagic eggs and larvae could be transported to adjacent bay or estuarine localities by oceanic currents. Some adults in the southern Brazil also may spawn offshore and that larvae and juveniles could enter various bays or estuaries at a later time (Barbieri, 1986). Although larvae and juveniles appear to remain in the bays and estuaries, some adults move into deeper waters and are capable of forming offshore schools that can migrate extensively (Paiva-Filho, 1977).

Combined with white mouth croaker life history patterns and nuclear data, the present mtDNA analysis supported the idea that species dispersal capability resulted from the interaction between physical environment conditions and species ecological requirements, and that life history variation when present, showed an ecophenotypic basis.

In other marine fishes with similar life histories and/or the capability for long-distance dispersal, genetic divergence is also typically small, and most of the genetic variation occurs within localities (Avise, 1994). Hierarchical analysis of variance presented here showed that a similar large component of mtDNA variance was found within populations. The low "among group" variance 
component was likely to be the result of the narrow geographical range covered in this study and the part of the variance distributed among populations within groups could be attributed to the limited populations within each group. Thus, at the level of genetic resolution employed in this study, the null hypothesis that $M$. furnieri shared a common gene pool could not be refuted. RFLP technique proved sufficiently powerful to detect genetic heterogeneity within the north versus south region of $23^{\circ} \mathrm{S}$, but did not reveal structured genetic stocks within the Brazilian coast between $23^{\circ} \mathrm{S}$ and $34^{\circ} \mathrm{S}$. It would be interesting to apply this method on a larger geographical scale, with a sampling design that included more populations to investigate possible additional groupings. The hypothesized genetic stock boundary between south and southeastern Brazil could be tested further by using fine-scale markers such as microsatellites, or direct sequencing of the mitochondrial D-loop region to provide better resolution of geographic structure.

\section{ACKNOWLEDGEMENTS}

The authors thank to Universidade Federal do Pará - UFPA and Universidade Federal do Rio de Janeiro - UFRJ for providing PA and RJ samples. We are also grateful to Coordenação de Aperfeiçoamento de Pessoal de Nível Superior CAPES and to Fundação Universidade Federal do Rio Grande - FURG for supporting this research.

\section{RESUMO}

No presente estudo, a estrutura genético populacional da corvina, M. furnieri, foi determinada ao longo da costa do Brasil entre as latitudes $1^{\circ} \mathrm{S}$ e $34^{\circ} \mathrm{S}$, por meio da análise de fragmentos polimórficos de DNA mitocondrial (mtDNA) obtidos por enzimas de restrição (RFLP). Os objetivos foram: (1) documentar a magnitude da variação e a distribuição geográfica do mtDNA em M. furnieri, (2) testar a hipótese de subdivisão populacional em $M$. furnieri ao longo da costa do Brasil e (3) estimar níveis de diferenciação genética entre regiões, como base para o manejo pesqueiro e a conservação da espécie. A análise RFLP revelou um total de cinco haplótipos de mtDNA que apresentaram freqüências de distribuição geográfica diferentes. Os testes de distribuição das freqüências haplotípicas não revelaram heterogeneidade genética entre as costas sudeste e sul do Brasil, entre $23^{\circ} \mathrm{S}$ e $34^{\circ} \mathrm{S}(\mathrm{P}=0,263)$, mas houve diferenças significativas entre as regiões ao norte $\mathrm{e}$ ao sul de $23^{\circ} \mathrm{S}(\mathrm{P}<0,003)$. Os resultados da análise de variância molecular (AMOVA) detectaram subdivisão populacional entre as localidades ao norte e ao sul de $23^{\circ} \mathrm{S}\left(\mathrm{F}_{\mathrm{ST}}=0,322\right.$, $\mathrm{p}<0,03)$, mas não indicaram diferenciação genética de $23^{\circ} \mathrm{S}$ a $34^{\circ} \mathrm{S}\left(\mathrm{F}_{\mathrm{ST}}=0,008, \mathrm{p}=0,180\right)$. Os valores de distâncias genéticas foram estatisticamente significativos entre as amostras de M. furnieri nas regiões ao norte e ao sul de $23^{\circ} \mathrm{S}$ $(\mathrm{p}<0,05)$. O teste de correlação entre as matrizes de distâncias genéticas e distâncias geográficas (em milhas) revelou um componente geográfico significativo na distribuição do mtDNA ao longo da costa do Brasil. Estes dados confirmam a hipótese de uma única população de M. furnieri na costa centro-sul do Brasil, entre as latitudes de $23^{\circ}$ $\mathrm{S}$ e $34^{\circ} \mathrm{S}$, e indicam a existência de populações parcialmente isoladas ao norte e ao sul de $23^{\circ} \mathrm{S}$.

\section{REFERENCES}

Alamón, M. (1983), Diferenciación de poblaciones del género Micropogonias dentro de la sub- área platense. Tesis Licenciatura Oceanografía, Faculdad de Humanidades y Ciencias, Universidad de la República, Uruguay. 60 pp.

Avise, J. C. (1994), Molecular Markers, Natural History and Evolution. New York: Chapman and Hall.

Avise, J. C.; Arnold, J.; Ball, R. M.; Bermingham, E.; Lamb, T.; Neigel, J. E.; Reeb, C. A. and Sanders, N. C. (1987), Intraspecific Phylogeography: the mitochondrial DNA bridge between population genetics and systematics. Ann. Rev. Ecol. Syst., 18, 489-522.

Barbieri, L. R. R. (1986), Distribuição espacial e temporal de sciaenídeos juvenis no estuário da Lagoa dos Patos, RS, Brasil. Tese de Mestrado, Universidade do Rio Grande, Rio Grande do Sul, Brasil. 60 pp.

Bowen, B. W. and Avise, J. C. (1990), Genetic structure of Atlantic and Gulf of Mexico populations of sea bass, menhaden, and sturgeon: influence of zoogeographic factors and life-history patterns. Mar. Biol., 107, 371-181.

Chao, L. N. (1978), Western Central Atlantic (fishing area 31). In: Fisher, $\mathrm{W}$ (Ed.). FAO species identification sheets for fisheries purposes. Rome: FAO. v. 6. 
Chow, S. and Inoue, S. (1993), Intra- and interspecific restriction fragment polymorphism in mitochondrial genes of Thunnus tuna species. Bull. Natl. Res. Inst. Far Seas Fish., 30, 207-225.

Cotrina, C. P. (1986), Estudios biológicos sobre peces costeros con datos de dos campañas de investigación realizadas en 1981. 2. La corvina rubia (Micropogonias furnieri). Publ. Com. Téc. Mix. Fr. Mar., 1, 8-14.

Emilsson, I. (1961), The shelf and coastal waters off southern Brazil. Bolm. Inst. Oceanogr. Univ. São Paulo, 11, 101-112.

Excoffier, L.; Smouse, P. E. and Quattro, J. M. (1992), Analysis of molecular variance inferred from metric distances among DNA haplotypes: application to human mitochondrial DNA restriction data. Genetics, 131, 479-491.

Felsestein, J. (2000), PHYLIP (Phylogenetic Inference Package), version 3.5. University of Washington, Seattle.

Gold, J. R. and Richardson, L. R. (1991), Genetic studies in marine fishes. IV. An analysis of population structure in the red drum (Sciaenops ocellatus) using mitochondrial DNA. Fish. Res., 12, 213-241.

Graves, J. E.; McDowell, J. R. and Jones, M. L. (1992), A genetic analysis of weakfish, Cynoscion regalis stock structure along mid- Atlantic coast. Fish. Bull., 90, 469-475.

Haimovici, M. (1998), Present state and perspectives for the southern Brazil shelf demersal fisheries. Fish. Manage. Ecol., 5, 277-289.

Isaac, V. J. (1988), Synopsis of biological data on the white mouth croaker Micropogonias furnieri (Desmarest, 1823). FAO Fisheries Synopsis, 150, 35.

Juras, A. A. (1984), Estudo sobre reprodução, regime alimentar e crescimento de Micropogonias furnieri (Desmarest, 1823) (Teleostei, Sciaenidae), capturada no litoral da Ilha de São Luiz do Maranhão - Brasil. Tese de Doutorado, Instituto Oceanográfico, Universidade de São Paulo. 205 pp.

Lankford Jr., T. E.; Targett, T. E. and Gaffney, P. M. (1999), Mitochondrial DNA analysis of population structure in the Atlantic croaker, Micropogonias undulatus (Perciformes: Sciaenidae). Fish. Bull., 97, 884-890.

Levy, J. A.; Maggioni, R. and Conceição, M. B. (1998), Close genetic similarity among populations of the white croaker (Micropogonias furnieri) in the south and south- eastern Brazilian coast. I. Allozyme studies. Fish. Res., 39, 87-94.

Lima, I. D.; Garcia, A. E. and Möller Jr., O. O. (1996), Ocean surface processes on the southern Brazilian shelf: characterization and seasonal variability. Cont. Shelf Res., 16, 1307-1317.

Lowe-McConnell, R. H. (1966), The Sciaenidae fishes of British Guiana. Bull. Mar. Sci., 16 : (1), 20-57.
Maggioni, R.; Pereira, A. N.; Jerez, B., Marins, L. F.; Conceição, M. B. and Levy, J. A. (1994), Estudio preliminar de la estructura genética de la corvina Micropogonias furnieri entre Rio Grande (Brasil) y El Rincón (Argentina). Frente Maritimo, 15, (Sec.A), 127-131.

Matsuura, Y. (1995), Os ecossistemas brasileiros e os principais macrovetores de desenvolvimento. Subsídio ao Planejamento da Gestão Ambiental. Projeto Cenários para o Planejamento da Gestão Ambiental (MMA/PNMA), Brasília, DF. pp. 39-104.

Nei, M. (1987), Molecular Evolutionary Genetics. New York: Columbia University Press.

Nei, M. and Li, W. (1979), Mathematical model for studying variation in terms of restriction endonucleases. Proc. Natl. Acad. Sci. USA, 76 : (10), 5269-5273.

Odebrecht, C. and Castello, J. P. (2001), The convergence ecosystem in the southwest Atlantic. In: Seeliger, U. and Kjerfve, B. (Eds.). Ecological Studies. Coastal Marine Ecosystem of Latin America, Springer-Verlag Berlin Heidelberg. v. 144.

Paiva-Filho, A. M. (1977), Estudo comparativo do aspecto dinâmico da estrutura espacial das populações de Micropogon furnieri (Desmarest, 1823) e Macrodon ancylodon (Block and Schneider, 1801) na costa brasileira entre as latitudes $28^{\circ} 30^{\prime} \mathrm{S}$ e $33^{\circ} \mathrm{S}$. Tese de Doutorado, Instituto Oceanográfico da Universidade de São Paulo, Brasil. 165 pp.

Raymond, M., and Rousset, F. (1995), An exact test for population differentiation. Evolution, 49, 1280-1283.

Sambrook, J.; Fritsch, E. F. and Maniatis, T. (1989), Molecular cloning: a laboratory manual. $2^{\text {nd }}$ ed. New York: Cold Spring Harbor Laboratory Press.

Schneider, S.; Roessli, D. and Excoffier, L. (2000), Arlequin ver. 2000: A software for population genetics data analysis. Genetics and Biometry Laboratory, University of Geneva, Switzerland.

Slatkin, M. (1987). Gene flow and the geographic structure of natural populations. Science, 236, 787-792.

Stramma, L. and England, M. (1999), On the masses and mean circulation of the South Atlantic Ocean. $J$. Geophys. Res., 104 : (C9), 20863-20883.

Vazzoler, A. E. A. M. (1971), Diversificação fisiológica e morfológica de Micropogon furnieri (Desmarest, 1822) ao sul de Cabo Frio, Brasil. Bolm. Inst. Oceanogr. Univ. São Paulo, 20 : (2), 1-70.

Vazzoler, A. E. A. M. (1963), Deslocamentos sazonais da corvina relacionados com as massas d'água. Contrib. Inst. Oceanogr. Univ. São Paulo (Sér. Oceanogr. Biol.), 5, 1-3.

Vazzoler, A. E. A. M. and Santos, E. P. (1965), Migração da corvina, Micropogon furnieri, na costa sul do Brasil. Bolm. Inst. Oceanogr. Univ. São Paulo, 14, 125-128. 
Whitlock, M. C. and McCauley, D. E. (1999), Indirect measures of gene flow and migration: $\mathrm{F}_{\mathrm{ST}}$ not equal to $1 /(4 \mathrm{Nm}+1)$. Heredity, 82, 117-125.

Wilson, A. C.; Cann, R. L.; Carr, S. M.; George, M.; Gyllensten, U. B.; Helm-Bychowski, K. M.; Higuchi, R. G.; Palumbi, S. R.; Prager, E. M.; Sage, R. D. and Stoneking, M. (1985), Mitochondrial DNA and two perspectives on evolutionary genetics. Biological Journal of the Linnean Society, 26, 375-400.

Received: January 24, 2005; Revised: July 18,2005 Accepted: January 23, 2006. 